\title{
FAKTOR YANG BERHUBUNGAN DENGAN CAKUPAN PEMERIKSAAN INSPEKSI VISUAL ASAM ASETAT (IVA) DI KOTA KENDARI
}

\section{Factors Connected With Coverage Of Visual Infection Of Acetic Acid Inspection (Iva) In Kendari City}

\author{
Asni Jaya ${ }^{1}$,Timbul Supodo ${ }^{2}$, Fatmawati ${ }^{3}$ \\ 1. STIKES Mandala Waluya Kendari \\ 2. POLTEKES Gizi Kendari
}

\section{Riwayat artikel}

Diajukan: Maret 2020

Diterima: September 2020.

\section{PenulisKorespondensi:}

- Asni Jaya

- STIKES Mandala Waluya Kendari

- asnijayasyarifuddinus man@yahoo.com

\section{Kata Kunci:}

Pengetahuan,Sikap, Dukungan Suami, Dukungan Petugas,Kondisi Ekonomi

\begin{abstract}
Abstrak
Saat ini cakupan deteksi dini kanker leher rahim di Kota Kendari melalui pemeriksaan Inspeksi visual asam asesat (IVA) masih sangat rendah (sekitar 5\%), padahal cakupan deteksi dini yang efektif dalam menurunkan angka kesakitan dan angk kematian karena kanker leher rahim adalah 85\%. Tujuan penelitian ini adalah untuk mengetahui faktor yang berhubungan dengan cakupan pemeriksaan Inspeksi visual asam asetat (IVA) di Kota Kendari.bJenis penelitian ini adalah kuantitatif dengan desain case control. Populasi dalam penelitian ini, terbagi menjadi dua yaitu populasi kasus adalah wanita usia subur usia yang pernah melakukan deteksi dini kanker serviks di Kota Kendari yaitu sebanyak 606 orang sedangkan populasi kontrol sebanyak 94.403 orang. Besar sampel masing-masing kelompok sebanyak 83 responden, yang diambil dengan cara simple random sampling. Data dikumpulkan dengan kuisioner, kemudian dianalisis secara deskriptif dan inferensial dengan menggunakan uji Chi Square. Hasil penelitian menunjukkan bahwa terdapat hubungan pengetahuan dengan rendahnya cakupan pemeriksaan Inspeksi visual asam aseta (IVA) di Kota Kendari, dimana diperoleh nilai $\mathrm{X}^{2}$ hitung $>\mathrm{X}^{2}$ tabel $(48,824>3,841)$. Terdapat hubungan sikap dengan rendahnya cakupan pemeriksaan Inspeksi visual asam aseta (IVA) di Kota Kendari, dimana diperoleh nilai $\mathrm{X}^{2}$ hitung $>\mathrm{X}^{2}$ tabel $(36,763>3,841)$.Terdapat hubungan dukungan suami dengan rendahnya cakupan pemeriksaan Inspeksi visual asam aseta (IVA) di Kota Kendari, dimana diperoleh nilai $\mathrm{X}^{2}$ hitung $>\mathrm{X}^{2}$ tabel $(75,841>3,841)$. Terdapat hubungan dukungan petugas kesehatan dengan rendahnya cakupan pemeriksaan Inspeksi visual asam aseta (IVA) di Kota Kendari, dimana diperoleh nilai $\mathrm{X}^{2}$ hitung > $\mathrm{X}^{2}$ tabel $(63,134>3,841)$.Terdapat hubungan kondisi ekonomi dengan rendahnya cakupan pemeriksaan Inspeksi visual asam aseta (IVA) di Kota Kendari, dimana diperoleh nilai $\mathrm{X}^{2}$ hitung $>\mathrm{X}^{2}$ tabel $(6,300>3,841)$. Oleh karena itu, perlunya lebih meningkatkan kegiatan sosialisasi terkait pemeriksaan Inspeksi Visual Asam Asetat
\end{abstract} (IVA).

Currently the scope for early detection of cervical cancer in Kendari through examination of infection visually acid asesat (IVA) is still very low (around 5\%), whereas coverage early detection are effective in reducing morbidity and angk deaths due to cervical cancer is $85 \%$. The purpose of this study was to determine the factors associated with infection visual inspection coverage acetic acid (VIA) in Kendari. This type of research is quantitative with case control design. The population in this study, divided into two populations is the case of reproductive age women who had had early detection of cervical cancer in Kendari as many as 606 people, while the population control as much as 94403 people. The sample size of each group were 83 respondents, who were taken by simple random sampling. Data were collected by questionnaire, and then analyzed by descriptive and inferential using Chi Square tes. The results showed that there is a relationship of knowledge with low coverage infection visual inspection of acetate acid (IVA) in Kendari, which gained value X2 count> X2 table (48.824> 3.841 ). Terdapat relationship with a lower attitude coverage infection visual inspection of acetate acid (VIA) in Kendari, which gained value X2 count> X2 table (36.763> 3.841) .Terdapat husband support relationships with low coverage infection visual inspection of acetate acid (IVA) in Kendari, which gained value X2 count> X2 table (75.841> 3.841) .Terdapat relationships support healthcare workers with low coverage infection visual inspection of acetate acid (IVA) in Kendari. 


\section{Pendahuluan}

Kanker Serviks (kanker leher rahim) adalah Tumbuhnya sel-sel kanker yang ganas dalam jaringan Leher rahim.Kanker serviks merupakan jenis penyakit kanker yang menyerang wanita dimana jumlah penderitanya cenderung meningkat beberapa tahun terakhir. Sekitar sepertiga dari seluruh penderita kanker di indonesia adalah Jenis kanker serviks (Anonim, 2015). Kanker serviks merupakan penyebab kematian kedua terbanyak pada wanita, tahun 2009 diperkirakan diseluruh dunia, dengan insiden kanker serviks sebesar 2540/100.000 wanita pertahun (Rasjidi, 2007).

Pada negara berkembang seperti negara Argentina, Brazil, Chili, Peru, Afrika Selatan, Cina, India dan Thailand kematian yang disebabkan kanker serviks menduduki urutan pertama yaitu lebih besar dari kematian maternal. Diseluruh dunia terlihat adanya disparitas gender untuk masalah kesehatan. Dan lebih menonjol di negara berkembang. Isu kesehatan seperti perawatan kesehatan dasar, face life debilitating dan life threatening yang kurang tersedia dan memadai, kematian ibu, menkah usia muda, HIV, dan kanker serviks adalah masalah kesehatan yang ditemui di negara negara berkembang (Dwipyono, 2011).Termaksud Indonesia, setiap tahun tidak kurang dari 15.000 kasus kanker leher rahim terjadi di Indonesia. Itu membuat kanker leher rahim disebut sebagai penyakit pembunuh nomor satu di Indonesia, hal tersebut dikarenakan tiap hari di Indonesia dari 40 wanita yang terdiagnosa menderita kanker leher rahim, 20 diantaranya meninggal dunia karena kanker leher rahim (Kementerian Kesehatan RI, 2015).

Data Kementerian Kesehatan Republik Indonesia (Kemenkes RI) pada tahun 2013, kejadian kanker serviks di Indonesia sebesar $0,8 \%$. Provinsi yang memiliki estimasi jumlah penderita kanker serviks terbesar adalah Provinsi Jawa Timur dengan estimasi 21.313 kasus. Sedangkan Provinsi Sultra sendiri tercatat pada tahun 2015 jumlah pasien dengan diagnose $\mathrm{Ca}$ Cerviks berjumlah 210, tahun 2016 berjumlah 189, tahun 2017 berjumlah 261 (RSUD Bahteramas, 2017).

Meningkatnya jumlah kasus baru kanker serviks di Indonesia pada setiap tahunnya, dapat menjadi ancaman besar bagi dunia kesehatan, karena mayoritas penderita kanker serviks baru terdeteksi pada stadium lanjut. Padahal kanker serviks dapat di cegah dan diatasi jika wanita usia subur lebih awal mempunyai pengetahuan yang baik dan kesadaran melakukan deteksi dini berupa test pap smear secara rutin serta melakukan imunisasi vaksin HPV untuk memperkecil risiko terkena kanker serviks. Selain itu kebiasaan pola hidup yang baik harus diperhatikan dengan menjaga pola makan, menghindari rokok, dan menjauhi alkohol(Sulistiowati and Sirait, 2014).

Insiden kanker leher rahim sebenarnya dapat ditekan dengan melakukan upaya pencegahan primer seperti meningkatkan atau intensifikasi kegiatan penyuluhan kepada Febriani, Faktor-faktor yang Berhubungan dengan Deteksi Dini Kanker Leher Rahim masyarakat untuk menjalankan pola hidup sehat, menghindari faktor risiko terkena kanker, melakukan immunisasi dengan vaksin Human Papillomavirus (HPV) dan diikuti dengan deteksi dini kanker leher rahim tersebut melalui pemeriksaan pap smear atau inspeksi visual dengan menggunakan asam acetat (IVA) (Sabrina, 2015). Saat ini cakupan deteksi dini kanker leher rahim di Indonesia melalui pap smear dan infeksi visual asam acecat (IVA) masih sangat rendah (sekitar 5\%), padahal cakupan deteksi dini yang efektif dalam menurunkan angka kesakitan dan angka kematian karena kanker leher rahim adalah $85 \%$ (Saslow et al., 2012). Beberapa faktor hambatan pemeriksaan IVA, diantaranya adalah perilaku wanita usia subur yang enggan untuk diperiksa karena kurangnya pengetahuan pasangan usia subur (PUS) tentang pap smear rasa malu dan rasa takut untuk memeriksa organ reproduksi kepada tenaga kesehatan, faktor biaya khususnya pada golongan ekonomi lemah, sumber informasi dan fasilitas atau pelayanan 
kesehatan yang masih minim untuk melakukan pemeriksaan pap smear (Schiffman \& Solomon, 2013).

Data dari Kementrian Kesehatan RI, sampai tahun 2017 cakupan deteksi dini kanker serviks IVA (Infeksi Visual Asam Acecat) hanya sebesar 2,98\% saja dengan cakupan tertinggi di Provinsi Kepulauan Bangka Belitung sebesar 13,9\% dan terendah adalah Provinsi Sulawesi tenggara sebesar $0,43 \%$. Hal ini sangat jauh dengan target nasional sebesar 50\% WUS (Wanita Usia Subur) melakukan deteksi dini kanker serviks metode infeksi visual asam acecat (IVA). Data tersebut juga diketahui, terdapat 105.418 orang IVA positif dan3.601 orang curiga kanker leher rahim (Kementerian Kesehatan RI, 2017).

Berdasarkan Data yang diperoleh dari Dinas Kesehatan Kota Kendari, diketahui bahwa, masih sangat sedikit sekali perempuan yang mau melakukan pemeriksaan IVA ( Infeksi Visual Asam Acecat). Tercatat tahun 2015 cakupan deteksi dini kanker serviks sebanyak 11 orang atau hanya $0,02 \%$ dari total penduduk perempuan usia 30 - 50 tahun dan terdapat satu orang IVA ( Infeksi Visual Asam Acecat) positif. Tahun 2016 cakupan deteksi dini kanker serviks sebanyak 418 orang atau hanya $0,9 \%$ dari total penduduk perempuan usia 30 - 50 tahun dan terdapat 15 orang IVA positif. Tahun 2017 cakupan deteksi dini kanker serviks sebanyak 606 orang atau hanya $0,64 \%$ dari total penduduk perempuan usia 30 - 50 tahun dan terdapat lima orang IVA Positif (Dinkes Kota Kendari, 2018).

Dari uraian data di atas penulis berkeinginan untuk melakukan penelitian dengan judul "Faktor Yang Berhubungan Dengan Rendahnya Cakupan Pemeriksaan Infeksi Visual Asam Acecat (IVA) Di Kota Kendari”.

\section{Metodologi}

Jenis penelitian dalam penelitian ini adalah kuatitatif dengan menggunakan rancangan Case ControlStudy.Populasi dalam penelitian ini adalah seluruh ibu atau wanita usia subur usia yang pernah melakukan deteksi dini kanker serviks di Kota Kendari yaitu sebanyak 606 orang. Sedangkan populasi kontrol adalah seluruh wanita usia subur (WUS) yang ada di Puskesmas Kota Kendari yaitu sebanyak 94.403 WUS.Besar sampel kasus dan kontrol masing-masing sebanyak 83 responden. Data dikumpulkan dengan kuisioner kemudian dianalisis secara deskriptif dan inferensial menggunakan $C h i$ Square dan Odd Ratio.

\section{Hasil dan Pembahasan}

\section{Hubungan pengetahuan dengan cakupan pemeriksaan infeksi visual asam asetat (IVA)}

Pengetahuan merupakan faktor yang penting namun tidak memadai dalam perubahan perilaku kesehatan. Pengetahuan seseorang mengenai kesehatan mungkin penting sebelum perilaku terjadi, tetapi tindakan kesehatan yang di harapkan mungkin tidak akan terjadi kecuali seseorang mempunyai motivasi untuk bertindak atas dasar pengetahuan dikatakan sebagai alat yang dapat digunakan untuk memecahakan masalah yang di hadapi manusia sengga melalui pengetahuan yang didapat orang akan mencari alat untuk memecahkan masalahnya, dan terkait kanker leher rahim maka orang pengetahuan yang dimilikinya (Notoatmodjo S, 2013).

Hasil penelitian ini menunjukkan bahwa, dari 85 responden dengan pengetahuan kurang terdapat 65 responden $(76 \%)$ yang tidak pernah melakukan pemeriksaan infeksi visual asam asetat (IVA). Hal ini menggambarkan bahwa kurangnya pengetahuan akan mempenggaruhi ibu atau WUS untuk tidak melakukan pemeriksaan IVA yang di mungkinkan karena kurang mendapatkan informasi baik melalui TV, radio, brosur maupun leaflet. Rendahnya tingkat pengetahuan WUS di Puskesmas Kota Kendari tentang pemeriksaan IVA, juga disebabkan karena kurangnya promosi 
dan sosialisasi dari petugas ke masyarakat tentang pentingnya pencegahan kanker serviks dengan cara deteksi dini melalui pemeriksaan IVA. Menurut wawancara peneliti juga diketahui bahwa selain dari kurangnya pengetahuan WUS tentang pemeriksaan IVA, juga disebabkan kondisi puskesmas, dimana tidak semua puskesmas melakukan menyediakan fasilitas Tes IVA di karenakan fasilitas kesehatan yang kurang di berapa puskesmas. Hal ini sejalan dengan teori yang menyatakan bahwa fasilitas pelayanan kesehatan yang ada di Puskesmas berhubungan terhadap keikutsertaan WUS dalam pemeriksaan infeksi visual asam asetat (IVA) (Kurniawati, 2015).

Dan dari 85 responden dengan pengetahuan kurang juga terdapat 20 responden (24\%) yang pernah melakukan pemeriksaan infeksi visual asam asetat (IVA). Wanita Usia Subur yang tidak melakukan pemeriksaan IVA meskipun mempunyai pengetahuan yang baik disebabkan karena responden ini tidak mempunyai penggalaman tentang pemeriksaan IVA kemudian di tambah lagi rendahnya kesadaran responden, tidak tersedianya informasi yang jelas di Puskesmas kapan akan dilakasanakan pemeriksaan IVA hingga rendahnya dukungan suami terhadap pencegahan dini kanker serviks juga turut mempengaruhi responden ini tidak melakukan pemeriksaan IVA. Hal ini sesuai teori yang menyatakan bahwa pengetahuan yang tinggi belum tentu menjamin seseorang untuk memiliki perilaku kesehatan yang baik. Hal ini disebabkan karena, selain pengetahuan, ada beberapa faktor lain yang turut mempenggaruhi perilaku responden diantaranya adalah kepercayaan, keyakinan, nilai-nilai, tersedia tidaknya fasilitas atau sarana kesehatan serta perilaku petugas kesehatan (Notoatmodjo S, 2013).
Sedangkan dari 81 responden dengan pengetahuan baik terdapat 18 responden $(22 \%)$ yang tidak pernah melakukan pemeriksaan infeksi visual asam asetat (IVA). Terdapatnya responden dengan pengetahuan kurang tapi melakukan pemeriksaan IVA dikarenakan responden ini hanya sekedar coba- coba dan tanpa menggetahui bahwa Tes IVA adalah salah satu pencegahan terjadinya infeksi pada rahim dan salah satu cara untuk mencegah terjadinya kanker serviks tetapi hanya sekedar membersihkan leher rahim agar tidak terjadi keputihan. Hasil wawancara peneliti, diperoleh informasi bahwa responden mengikuti pemeriksaan IVA karena ajakan dengan temannya. Hal ini sesuai dengan teori yang menyatakan bahwa ibu yang melakukan pemeriksaan IVA karena adanya dukungan sosial dari lingkungannya (Seri, 2016).

Hal ini juga terlihat dari hasil analisis data dengan menggunakan uji Chi Square, diperoleh nilai X2 hitung > X2 tabel $(48,824>3,841)$, koefisien $\operatorname{Phi}(\Phi)$ sebesar 0,524, artinya terdapat hubungan yang sedang antara pengetahuan dengan cakupan pemeriksaan infeksi visual asam asetat (IVA). Penelitian ini sejalan dengan penelitian yang dilakukan di Puskesmas Alianyang Pontianak yang menyatakan bahwa terdapat hubungan antara pengetahuan dengan keikutsertaan WUS dalam pemeriksaan IVA (Mirayashi, 2014). Penelitian ini juga sejalan dengan penelitian yang dilakukan pada Wanita Usia Subur Tentang Kanker Serviks Dengan Keikutsertaan Iva Test Di Puskesmas Umbulharjo Yogyakarta yang menyatakan bahwa terdapat hubungan antara pengetahuan dengan perilaku WUS dalam pemeriksaan infeksi visual asam asetat (IVA) (Nurani \& Ratnaningsih, 2017)

2. Hubungan sikap dengan cakupan pemeriksaan infeksi visual asam asetat (IVA) 
Sikap adalah respons tertutup seseorang terhadap stimulus atau objek tertentu, yang sudah melibatkan faktor pendapat dan emosi yang bersangkutan (senang-tidak senang, setuju-tidak sétuju, baik-tidak baik, dan sebagainya (Notoatmodjo S 2013). Hasil penelitian ini menunjukkan bahwa, dari 87 responden dengan sikap kurang terdapat 63 responden $(72 \%)$ yang tidak pernah melakukan pemeriksaan infeksi visual asam asetat (IVA). Hal disebabkan karena sebagian dari responden ini merasa malu karena pada saat pemeriksaan infeksi visual asam asesat (IVA) melibatkan organ genital atau organ intim wanita. Kemudian ada juga beberapa responden merasa yang takut nanti bakal sakit. Hal ini juga bila ditelaah lebih dalam disebabkan karena rendahnya tingkat pengetahuan responden mengenai pentingnya pemeriksaan infeksi visual asam asesat (IVA) Hal ini sesuai dengan teori yang menyatakan bahwa adanya persepsi yang kurang dari responden mengenai pemeriksaan IVA dikarenakan adanya tingkat persepsi yang dimiliki responden mengenai kanker serviks dan bahaya yang menyertainya (Rahmadhan, Fidiawati, \& Suyanto, 2016). Hal ini juga sejalan dengan penelitian yang dilakukan oleh (Yuli, 2010)yang menyatakan bahwa terdapat hubungan yang kuat antara rasa malu dengan tindakan tidak mendeteksi dini kanker leher rahim.

Sikap responden yang kurang juga dapat dipengaruhi oleh tingkat pendidikan yang telah dilalui oleh responden. Dengan adanya tingkat pengetahuan melalui jalur formal mengenai kanker servis dapat menciptakan persepsi yang baik mengenai cara pencegahan dan upaya deteksi dini yang harus dilakukan oleh wanita usia subur. Orang dengan tingkat pendidikan yang baik akan cenderung lebih mudah menerima perubahan yang bersifat baik dibandingkan dengan orang yang tidak memiliki dasar tingkat pendidikan yang akan cenderung akan bersifat tertutup dan sulit untuk menerima perubahan perilaku tersebut (Ariwibowo, 2013).

Dan dari 87 responden dengan sikap kurang juga terdapat 24 responden (28\%) yang pernah melakukan pemeriksaan infeksi visual asam asetat (IVA). Hal ini dikarenakan beberapa faktor laindiantaranya sebagian Puskesmas tidak menyediakan fasilitas pemeriksaan infeksi visual asam asetat (IVA). Selain itu faktor kondisi ekonomi dan kurangnya dukungan suami dan petugas juga turut mempengaruhi masyarakat enggan melaksanakan pemeriksaan IVA. Hal ini sesuai dengan teori yang menyatakan bahwa dengan adanya dukungan sosial dapat meningkatkat perilaku pencegahan terhadap kanker serviks (Dewi, 2014). Hal ini juga sejalan dengan penelitian yang dilakukan pada remaja putri di Madrasah Aliyah Negeri Darussalam Kabupaten Aceh Besar yang menyatakan bahwa sebanyak $62.9 \%$ reponden berperilaku pencegahan kanker serviks yang baik disebabkan karena adanya dukungan sosial atau teman sebaya (Efrida, 2018).

Sedangkan dari 79 responden dengan sikap baik terdapat 20 responden (25\%) yang tidak pernah melakukan pemeriksaan infeksi visual asam asetat (IVA). Hal ini memberikan gambaran bahwa sikap yang baik belum tentu dapat merubah perilaku seseorang untuk melaksanakan pemeriksaan IVA, akan tetapi ada faktor lain yang dapat menyebabkan seseorang berperilaku. Faktor yang cukup dominan dalam membentuk suatu perilaku adalah niat dari orang tersebut, semakin kuat niat semakin cepat pulsa seseorang dapat berubah (Akmal, Widjanarko, \& Nugraha, 2017).

Dan dari 79 responden dengan sikap baik terdapat 59 responden $(75 \%)$ yang pernah melakukan pemeriksaan 
asam asetat (IVA).Hal ini menunjukkan sikap baik responden tentang deteksi dini kanker serviks dengan IVA. Hal ini berkaitan dengan Faktor-faktor yang mempengaruhi sikap seseorang adalah Pengaruh orang lain yang dianggap penting pada umumnya yaitu petugas kesehatan yang memberikan pendidikan kesehatan kepada wanita usia subur sebagain deteksi dini kanker serviks sehingga menambah ilmu pengetahuan bagi wanita usia subur sehingga akan mempengaruhi sikap wanita usia subur untuk melakukan deteksi dini kanker serviks dengan metode IVA, individu cenderung untuk memiliki sikap yang konformis atau searah dengan pemikiran orang lain yang dianggap penting tersebut (Wawan \& Dewi, 2010). Hasil ini juga terlihat dari hasil uji keeratan hubungan yang menunjukkan bahwa kekuatan hubungan antara antara sikap dengan cakupan pemeriksaan infeksi visual asam asetat (IVA) di Kota Kendari kategori hubungan sedang.

Hasil analisis data dengan menggunakan uji Chi Square, diperoleh nilai X2 hitung $<$ X2 tabel $(36,763>$ 3,841 ), artinya terdapat hubungan yang bermakna antara sikap dengan cakupan pemeriksaan infeksi visual asam asetat (IVA). Hasil penelitian ini sejalan dengan penelitian yang dilakukan di Kelurahan Kotabaru Wilayah Kerja Puskesmas Gondokusuman Ii Yogyakarta yang menyatakan bahwa terdapat hubungan antara sikap dengan keikutsertaan dalam pemeriksaan infeksi visual asam asetat (Lestari, 2016). Penelitian ini juga sejalan dengan penelitian yang dilakukan Di Kelurahan Candirejo Kabupaten Semarang yang menyakan bahwa ada hubungan antara sikap dengan keikutsertaan dalam pemeriksaan infeksi visual asam asetat (IVA) (Astuti, Setyowati, \& Salafas, 2017).

3. Hubungan dukungan suami dengan cakupan pemeriksaan infeksi visual asam asetat (IVA)
Hasil penelitian ini menunjukkan bahwa, dari 78 responden dengan dukungan suami kurang terdapat 67 responden $(86 \%)$ yang tidak pernah melakukan pemeriksaan infeksi visual asam asetat (IVA). Hal ini disebabkan karena budaya masyarakat yang masih sangat kental, dimana istri menempatkan suami sebagai penentu pengambil keputusan dalam melakukan pemeriksaan kesehatan atau dalam hal ini pemeriksaan infeksi visual asam asetat (IVA).Sehingga dukungan suami sangat bermakna dalam perilaku ibu, karena seringkali bertindak sebagai pengambil keputusan terhadap upaya pemeliharaan kesehatan keluarganya. Dukungan suami merupakan salah satu bagian reinforcing factors, artinya semakin besar dukungan yang berikan oleh suami atau pasangan untuk melakukan pemeriksaan IVA, maka akan terjadi perubahan perilaku ibu untuk melakukan Tes IVA secara berkala. Dukungan suami yang dimaksud adalah dukungan yang dapat memotivasi ibu dalam melakukan pemeriksaan infeksi visual asam asetat (IVA) (Yustisianti \& Suryaningsih, 2017).

Hal ini juga bila ditelaah lebih dalam disebabkan karena kurangnya pengetahuan suami terkait pentingnya pencegahan terjadinya kanker serviks dengan cara deteksi dini kanker serviks melalui pemeriksaan infeksi visual asam asetat (IVA). Hal sejalan dengan teori yang menyatakan bahwa dukungan suami menjadi faktor penentu karena dukungan pasangan akan memberikan penguatan terhadap motivasi untuk melakukan deteksi dini kanker serviks. Suami yang mempunyai pemahaman lebih dapat memberikan penjelasan dan dukungannya pada istri untuk melaksanakan perilaku sehat (Wahyuni, 2013).

Dan dari 78 responden dengan dukungan suami kurang juga terdapat 11 responden (14\%) yang pernah melakukan pemeriksaan infeksi visual asam asetat (IVA).Hal ini disebabkan karena 11 responden ini telah memiliki pengetahuan 
dan kesadaran yang cukup baik tentang pencegahan dini kanker serviks melalui pemeriksaan insfeksi visual asam asetat.Hal ini juga dikarenakan responden ini merupakan keluarga dari salah satu tenaga kesehatan yang ada bekerja di Puskesmas.Tenaga kesehatan inilah yang memberikan informasi dan konseling terhadap responden ini.

Sedangkan dari 88 responden dengan dukungan suami baik terdapat 16 responden (18\%) yang tidak pernah melakukan pemeriksaan infeksi visual asam asetat (IVA). Hal ini dikarenakan persepsi responden ini terkait pemeriksaan IVA, yang dimana ibu merasa malu karena yang diperiksa adalah alat kelaminnya dan responden juga merasa takut jika pada saat melakukan pemeriksaan IVA akan menimbulkan rasa sakit. Hal ini juga bila ditelaah lebih jauh disebabkan karena kurangnya pengetahuan dan sikap responden yang masih sangat kurang. Hasil sesuai dengan penelitian yang dilakukan di Dusun Pakatto Caddi Desa, yang menyatakan ada pengaruh pengetahuan suami terhadap dukungan suami dalam melakukan pemeriksaan IVA (Hasnita, 2018).

Hal ini terlihat dari hasil uji statistik dengan menggunakan uji Chi Square, diperoleh nilai X2 hitung > X2 tabel $(75,841>3,841)$, koefisien $\operatorname{Phi}(\Phi)$ sebesar 0,676 , artinya terdapat hubungan yang kuat antara dukungan suami dengan cakupan pemeriksaan infeksi visual asam asetat (IVA). Penelitian ini sejalan dengan penelitian yang dilakukan di Puskesmas Manahan Surakarta yang menyatakan terdapat hubungan antara dukungan suami dengan perilaku wanita usia subur dalam pemeriksaan IVA (Lestari et al., 2016). Penelitian ini juga sejalan dengan penelitian yang dilakukan di Wilayah Kerja Puskesmas Bangetayu Kota Semarang yang menyatakan bahwa dukungan suami merupakan faktor yang mempengaruhi perilaku WUS dalam melakukan pemeriksaan IVA (Masturoh, 2016)

\section{Hubungan dukungan petugas dengan cakupan pemeriksaan infeksi visual asam asetat (IVA)}

Peran petugas kesehatan adalah memberikan pengetahuan tentang kanker serviks dan pentingnya deteksi dini, serta memberikan motivasi kepada wanita yang sudah menikah untuk melakukan deteksi dini kanker serviks.Faktor dari tenaga kesehatan itu sebagai pendorong atau penguat dari individu untuk berperilaku.Hal ini dikarenakan petugas tersebut ahli dibidangnya sehingga dijadikan tempat untuk bertanya dan pemberi input/masukan untuk pemanfaatan pelayanan kesehatan. Hal ini juga akan mempengaruhi motivasi WUS untuk melakukan pemeriksaan IVA. Menurut Peneliti, mengenai ketidakikutan mereka dalam pemanfaatan IVA, hal ini disebabkan wanita usia subur kurang mendapatkan dukungan petugas kesehatan baik melalui penyuluhan atau petugas kesehatan mengajak langsung responden untuk melakukan pemeriksaan IVA. Penyampaian informasi yang baik antara petugas kesehatan dengan masyarakat dan antara masyarakat itu sendiri berkontribusi positif terhadap perilaku pemeriksaan deteksi dini kanker serviks. Penyampaian informasi dapat melalui cara formal penyuluhan, petugas kesehatan dapat menempuh cara non formal (pengajian, perwiridan). Penyampaian seperti itu kemungkinan dapat menjangkau masyarakat yang belum pernah atau jarang ke Puskesmas.

Dari hasil penelitian menunjukkan bahwa, dari 107 responden dengan dukungan petugas kurang terdapat 78 responden $(73 \%)$ yang tidak pernah melakukan pemeriksaan infeksi visual asam asetat (IVA). Hal ini disebabkan karena pelaksanaan pemeriksaan IVA di Puskesmas sifatnya tidak rutin karena pelaksaannya selalu berdasarkan program dari dinas kesehatan dan dari BPJS Kesehatan sehingga peran petugas 
puskemas relatif tidak terlaksana dengan optimal. dan terdapat 29 responden $(27 \%)$ dukungan petugas kurang dan pernah yang pernah melakukan pemeriksaan infeksi visual asam asetat (IVA). Hal ini disebabkan karena pengetahuan masyarakat relative cukup baik didukung dengan kesadaran yang tinggi. Sedangkan dari 59 responden dengan dukungan petugas baik terdapat 5 responden $(8 \%)$ yang tidak pernah melakukan pemeriksaan infeksi visual asam asetat (IVA) hal ini disebabkan karena tingkat aktivitas responden yang cukup tinggi sehingga menyebabkan responden tidak datang melakukan pemeriksaan IVA di Puskesmas dan 54 responden $(92 \%)$ yang pernah melakukan pemeriksaan asam asetat (IVA), hal ini disebabkan karena tingkat kesadaran responden relatif cukup baik dan didukung dengan pengetahuan petugas yang baik serta didukung dengan peran serta keluarga sehingga cakupan pemeriksaan IVA di puskesmas meningkat.

Sedangkan dari hasil uji statistik dengan menggunakan uji Chi Squarel, diperoleh nilai X2 hitung > X2 tabel $(63,134>3,841)$, artinya terdapat hubungan yang bermakna antara dukungan petugas dengan cakupan pemeriksaan infeksi visual asam asetat (IVA).Hasil uji keeratan hubungan menunjukkan koefisien Phi $(\Phi)$ sebesar 0,617 , hal ini menunjukkan kekuatan hubungan antara dukungan petugas dengan cakupan pemeriksaan infeksi visual asam asetat (IVA) di Kota Kendari kategori hubungan kuat. Penelitian ini sejalan dengan penelitian di Puskesmas Mandala, dimana diperoleh nilai $\rho$ value $=0,000$, yang menunjukkan adanya hubungan bermakna antara dukungan petugas kesehatan terhadap pemanfaatan pelayanan IVA (Tsari, 2018). Penelitian ini juga sejalan dengan yang dilakukan oleh (Rahmi, 2018), yang menyatakan bahwa dukungan petugas merupakan faktor penting dalam meningkatkan pengetahuan masyarakat dalam pemeriksaan infeksi visual asam asetat (IVA) di wilayah kerja Puskesmas Kuok.

\section{Hubungan kondisi ekonomi dengan cakupan pemeriksaan infeksi visual asam asetat (IVA)}

Hasil penelitian ini menunjukkan bahwa, dari 71 responden dengan kondisi ekonomi kurang terdapat 44 responden (62\%) yang tidak pernah melakukan pemeriksaan infeksi visual asam asetat (IVA). Hal ini lebih disebabkan karena kurangnya pengetahuan masyarakat tentang pemeriksaan IVA, sehingga terciptanya persepsi oleh masyarakat bahwa pemeriksaan infeksi visual asam asetat (IVA) berbayar atau mahal.Hal ini juga bila ditelaah lebih jauh disebabkan karena kurangnya sosialisasi dari petugas kesehatan tentang pemeriksaan IVA ini.Hasil pengamatan peneliti diketahui bahwa tidak adanya sosialisasi yang dilakukan oleh petugas kesehatan sehingga minat masyarakat untuk datang dan ikut serta dalam pemeriksaan IVA pun kurang. Hal ini sejalan dengan teori yang menyatakan bahwa petugas kesehatan merupakan faktor penting dalam meningkatkan keikutsertaan wanita usia subur dalam pemeriksaan IVA dengan cara memberikan konseling ataupun kegiatan-kegiatan promosi kesehatan lainnya (Febriani, 2016).

Dan dari 71 responden dengan kondisi ekonomi kurang juga terdapat 27 responden (38\%) yang pernah melakukan pemeriksaan infeksi visual asam asetat (IVA). Hal ini lebih disebabkan karena faktor lain diantaranya tingkat pengetahuan dan kesadaran responden ini yang sudah cukup baik terkait pentingnya pencegahan kanker serviks. Adanya dukungan sosial dari lingkungan seperti dukungan dari teman sejawat yang memberikan informasi dan mengajak ke Puskesmas untuk melakukan pemeriksaan IVA.Hasil wawancara mendalam peneliti juga diketahui bahwa beberapa responden memeriksakan diri ke Puskesmas karena adanya masalah 
dalam hubungan intim dengan pasangannya atau adanya keluhan dari pasangannya. Hal ini sejalan dengan penelitian yang dilakukan pada wanita dewasa awal di Desa Balung Lor, Kecamatan Balung, Kabupaten Jember yang menyatakan bahwa wanita yang melakukan pemeriksaan IVA disebabkan karena adanya gangguan dalam berhubungan dengan pasangannya (Musyriqoh, 2013)

Sedangkan dari 95 responden dengan kondisi ekonomi baik terdapat 39 responden $(41 \%)$ yang tidak pernah melakukan pemeriksaan infeksi visual asam asetat (IVA). Hal ini lebih disebabkan karena faktor lain, diantaranya adalah adanya rasa malu dan adanya rasa takut sakit bila melakukan pemeriksaan infeksi visual asam asetat (IVA). Hal ini menggambarkan bahwa kondisi ekonomi tidak terlalu berhubungan dengan perilaku wanita usia subur dalam melakukan pemeriksaan IVA. Hal ini terlihat dari hasil analisis data dengan menggunakan uji Chi Square, diperoleh nilai X2 hitung $<\mathrm{X} 2$ tabel $(6,300>3,841)$, koefisien $\operatorname{Phi}(\Phi)$ sebesar 0,217 artinya terdapat hubungan lemah antara kondisi ekonomi dengan cakupan pemeriksaan infeksi visual asam asetat (IVA). Penelitian yang dilakukan oleh (Anttila et al., 2010)yang menyatakan bahwa wanita dengan status sosial ekonomi rendah lebih berpeluang dua kali lipat dibandingkan dengan wanita status ekonomi tinggi untuk kanker serviks. Sedangkan penelitian dilakukan oleh (Dewi, 2014) diperoleh hasil yang berbeda yaitu tidak ada hubungan antara status ekonomi dengan perilaku pencegahan kanker serviks. Hal ini juga sejalan dengan penelitian yang dilakukan oleh (Wahyuni, 2013)yang menyatakan bahwa tidak terdapat hubungan antara status ekonomi dengan perilaku deteksi dini kanker serviks yang baik.

\section{Simpulan}

Berdasarkan hasil dan pembahasan pada penelitian ini dapat disimpulkan sebagai berikut:

1. Terdapat hubungan sedang antara pengetahuan dengan cakupan pemeriksaan infeksi visual asam aseta (IVA) di Kota Kendari, dimana diperoleh nilai X2 hitung $>\mathrm{X} 2$ tabel $(48,824>3,841)$, dan $(\Phi)=0,524$.

2. Terdapat hubungan sedang antara sikap dengan cakupan pemeriksaan infeksi visual asam aseta (IVA) di Kota Kendari, dimana diperoleh nilai X2 hitung $>$ X2 tabel $(36,763>3,841)$, dan $(\Phi)=0,470$.

3. Terdapat hubungan kuat antara dukungan suami dengan cakupan pemeriksaan infeksi visual asam aseta (IVA) di Kota Kendari, dimana diperoleh nilai X2 hitung $>\mathrm{X} 2$ tabel $(75,841>3,841)$, dan $(\Phi)=0,676$.

4. Terdapat hubungan kuat antara dukungan petugas kesehatan dengan cakupan pemeriksaan infeksi visual asam aseta (IVA) di Kota Kendari, dimana diperoleh nilai X2 hitung $>\mathrm{X} 2$ tabel $(63,134>3,841)$, dan $(\Phi)=0,617$.

5. Terdapat hubungan lemah antara kondisi ekonomi dengan cakupan pemeriksaan infeksi visual asam aseta (IVA) di Kota Kendari, dimana diperoleh nilai X2 hitung > X2 tabel $(6,300>3,841)$, dan $(\Phi)=0,217$.

\section{Daftar Pustaka}

Akmal, D., Widjanarko, B., \& Nugraha, P. (2017). Sikap Mempengaruhi Niat Berhenti Merokok pada Remaja SMA di Kota Bima. Jurnal Promosi Kesehatan Indonesia, 12(1), 78-91.

Anttila, A., Kotaniemi-Talonen, L., Leinonen, M., Hakama, M., Laurila, P., Tarkkanen, J., . . . Nieminen, P. (2010). Rate of cervical cancer, severe intraepithelial neoplasia, and adenocarcinoma in situ in primary HPV DNA screening with cytology triage: randomised study within organised screening programme. Bmj, 340, c1804.

Ariwibowo, R. (2013). Hubungan antara umur, tingkat pendidikan, pengetahuan, sikap terhadap praktik safety riding awareness pada pengendara ojek sepeda motor di Kecamatan Banyumanik. 
Jurnal Kesehatan Masyarakat Universitas

Diponegoro, 2(1).

Astuti, D. F., Setyowati, H., \& Salafas, E. (2017). Analisis Faktor Pemeriksaan Iva Dalam Upaya Deteksi Dini Kanker Serviks Di Kelurahan Candirejo Kabupaten Semarang. Paper presented at the Seminar Nasional Kebidanan.

Dewi, Y. I. (2014). Faktor-faktor yang berhubungan dengan perilaku pencegahan kanker serviks pada wanita usia subur. Jurnal Online Mahasiswa Program Studi Ilmu Keperawatan Universitas Riau, 1(2), 1-8.

Dinas Kesehatan Provinsi Sulawesi Tenggara. (2018). Profil Kesehatan Selawesi Tenggara Tahun 2017. Sulawesi Tenggara: Dinkes Sultra.

Dinkes Kota Kendari. (2018). Profil Kesehatan Kota Kendari. Kendari: Dinas Kesehatan Kota Kendari.

Efrida, M. (2018). Hubungan Pengetahuan Dan Minat Remaja Putri Dengan Pencegahan Kanker Serviks Di Madrasah Aliyah Negeri Darussalam Kabupaten Aceh Besar.

Febriani, C. A. (2016). Faktor-Faktor Yang Berhubungan Dengan Deteksi Dini Kanker Leher Rahim Di Kecamatan Gisting Kabupaten Tanggamus Lampung. Jurnal Kesehatan, 7(2), 228-237.

Hasnita, H. (2018). Pengaruh Dukungan Suami Dan Pengetahuan Ibu Terhadap Pelaksanaan Pemeriksaan Iva Di Dusun Pakatto Caddi Desa Pakatto. Jurnal Kebidanan Vokasional, 3(1), 43-49.

Kementerian Kesehatan Ri. (2015). Panduan Program Nasional Gerakan Pencegahan Dan Deteksi Dini Kanker Leher Rahim Dan Kanker Payudara. Jakarta: Kementerian Kesehatan Ri.

Kurniawati, I. (2015). Pengaruh Pengetahuan, Motivasi Dan Dukungan Suami Terhadap Perilaku Pemeriksaan Iva Pada Kelompok Wanita Usia Subur Di Puskesmas Kedungrejo. Universitas Sebelas Maret.

Lestari, M. A. (2016). Hubungan Pengetahuan Dan Sikap Wus Dengan Perilaku Melakukan Pemeriksaan Iva Di Kelurahan Kotabaru Wilayah Kerja Puskesmas Gondokusuman Ii Yogyakarta. Universitas' Aisyiyah Yogyakarta.

Masturoh, E. (2016). Faktor-Faktor Yang Mempengaruhi Wanita Usia Subur (Wus) Dalam Melakukan Deteksi Dini Kanker Serviks Metode Inspeksi Visual Asam Asetat (Iva). Universitas Negeri Semarang.

Mirayashi, D. (2014). Hubungan Antara Tingkat Pengetahuan Tentang Kanker Serviks Dan Keikutsertaan Melakukan Pemeriksaan Inspeksi Visual Asetat Di Puskesmas Alianyang Pontianak. Jurnal Mahasiswa Pspd Fk Universitas Tanjungpura, 1(1).

Musyriqoh, S. (2013). Hubungan Dukungan Suami Dengan Perilaku Pencegahan Terhadap Kanker Serviks Pada Wanita Dewasa Awal Di Desa
Balung Lor, Kecamatan Balung, Kabupaten Jember. Undergraduate Mini Thesis), Universitas Jember, Jember.

Notoatmodjo S. (2013). Promosi Kesehatan Dan Ilmu Perilaku. Pt Rineka Cipta. Jakarta.

Notoatmodjo S (2013). Ilmu Promosi Perilaku Jakarta Rineka Cipta.

Nurani, K. S., \& Ratnaningsih, S. (2017). Hubungan Pengetahuan Wanita Usia Subur Tentang Kanker Serviks Dengan Keikutsertaan Iva Test Di Puskesmas Umbulharjo Ii Yogyakarta. Universitas' Aisyiyah Yogyakarta.

Rahmadhan, R., Fidiawati, W. A., \& Suyanto, S. (2016). Hubungan Pengetahuan Dan Sikap Terhadap Tindakanwanita Pekerja Seksual Tidak Langsung Tentang Pap Smear Dan Inspeksi Visual Asetat Pada Sebagai Deteksi Dini Kanker Serviks Di Hotspot X Kecamatan Lima Puluh Pekanbaru. Jurnal Online Mahasiswa Fakultas Kedokteran Universitas Riau, 3(2), 1-15.

Rahmi, M. (2018). Hubungan Media Informasi Dan Persepsi Wanita Usia Subur Terhadap Pemeriksaan Iva Di Wilayah Kerja Puskesmas Kuok Tahun 2017. Menara Ilmu, 12(5).

Seri, M. (2016). Hubungan Karakteristik, Pengetahuan Dan Dukungan Keluarga Wanita Usia Subur Dengan Tindakan Pemeriksaan Iva Di Wilayah Kerja Puskesmas Padang Pasir Tahun 2016. Universitas Andalas.

Tsari, A. (2018). Hubungan Tingkat Pengetahuan Dengan Partisipasi Terhadap Deteksi Dini Kanker Serviks Di Puskesmas Mandala Tahun 2018.

Wahyuni, S. (2013). Faktor-Faktor Yang Mempengaruhi Perilaku Deteksi Dini Kanker Serviks Di Kecamatan Ngampel Kabupaten Kendal Jawa Tengah. Jurnal Keperawatan Maternitas, 1(1).

Wawan, A., \& Dewi. (2010). Teori Dan Pengukuran Pengetahuan Dan Perilaku Manusia. Yogyakarta: Nuha Medika.

Yuli, E. (2010). Pengaruh Persepsi Wanita Pasangan Usia Subur (Pus) Tentang Kanker Leher Rahim (Klr) Dan Program Inspeksi Visual Asetat (Iva) Terhadap Pemanfaatan Pelayanan Iva Di Wilayah Kerja Puskesmas Bandar Khalifah Kecamatan Percut Sei Tuan Kabupaten Deli Serdang Tahun 2010.

Yustisianti, E. N., \& Suryaningsih, E. K. (2017). Hubungan Dukungan Suami Dengan Perilaku Wanita Usia Subur (Wus) Melakukan Pemeriksaan Inspeksi Visual Asam Asetat (Iva) Di Puskesmas Kasihan I Bantul. Universitas' Aisyiyah Yogyakarta. 